\title{
The Role of the Monetary Policy in Achieving Economic Growth in Syria
}

\author{
Dr. Ghassan Farouk Ghandour \\ Lecturer, Department of Accounting and Information Technology, Faculty of Administrative and Financial \\ Sciences, Cihan University, Sulaymaniyah-Iraq.
}

\begin{abstract}
We can say that the monetary policy plays big role in different economics. In developing countries specially in Syria the monetary policy start to Take its turn in affecting economy after rebirth in 2003 and give it the independence in practicing the monetary policy. That is meaning the allowing to the economic laws to work far from the government wants. From the Syrian experience in this concern at the last three years we can say that we need some time to a good use of the tools of monetary policy and we must re design our policies to fit our requirement.
\end{abstract}

Keywords: monetary policy - economy - exchange rate - interest rate

\section{Introduction}

The economic policy consists of set of policies like monetary policy, fiscal policy, employment policy ...etc.

This policy related together in internal and complex relations who make them affect each other. The monetary policy is an important policy and its important became more and more over the last decades.

Syria as a developing country has its private terms which limit the useful use of the monetary policy .so I like to make a spot light on the Syrian monetary policy and its impacts on the whole economy.

Research hypotheses

In order to address the problem of this research and to facilitate the answer to the questions posed, we can develop a number of hypotheses based on the collected information, so we assume the following:

1. Monetary policy is one of the most important means of economic policy to influence economic activity

2. Monetary policy performance can be effective and efficient only if a set of standards and controls are available

Research importance

This research derives its importance from the position of monetary policy from the perspective of economic schools, its role in addressing economic imbalances, its position in the economic reform programs supported by the international financial institutions, and the transition to a market economy, which is more important than the position it enjoys This policy aims at achieving economic stability and driving growth as the most important parts or items of economic policy.

Research objectives

This research aims at reaching several points, the most important of which are:

1- Highlighting the theme of monetary policy in all its aspects to show its importance and role in economic activity as well as uncover mechanisms and methods of work and everything related to them

2- Attempt to evaluate the performance of the controls or criteria on which monetary policy is based in the national economy in light of the economic reforms adopted

\section{Research Methodology}

A combination of the descriptive curriculum and the analytical approach will be used as the descriptive approach relates to the review of school ideas and the presentation of the structure of the Syrian economy. The analytical approach was based on trying to understand the elements of monetary policy and reform programs, using the foundations and relations based on them, and diagnosing the problems that were raised, as well as trying to put a quantitative expression of the various stages experienced by the Syrian economy.

First: The conceptual frame work of the monetary policy

\section{1- Definition:}

Is a set of procedures regarding the money supply to affect the economic variables (saving, investment, prices, etc) to perform the general aims of the monetary policy.

$\boldsymbol{O r}$ the central bank policy regarding the supply of money in the economy.

The central bank influences the level of the economic activities by controlling the amount of money. 
2- Tools of the monetary policy:

There are number of ways in which central bank apply its monetary policy:

1. Money supply (increase or decrease).

2. Interest rate.

3. Rediscount rate.

4. Open operation.

5. The legal reserve ratio.

Monetary policy can take one of three forms:

* Controlling the supply of money.

- Controlling interest rate.

- Rationing the amount of credit granted by banks.

3- Aims of the monetary policy:

The prime opgective of the monetary policy in all countries is

Achieving price stability by controlling inflation which is essential for sustained economic growth.

There are other opgectives which called magic square:

1. High growth rates.

2. Complete use of resources.

3. Stability of exchange rate.

4. Equiponderate of payment balance.

In framing its monetary policy government must address number of important questions:

- What are the goals of monetary policy? Is the aim simply to control inflation? Or does the government wish also to affect out put and employment? Or does it want to control exchange rate?

* Does the monetary policy fit the total package of macro economic policies?

- What element of the monetary system should the government seek to control? Should it be the supply of money? Or the demand of money? Or the interest rate?

* Should the government take long term or short term perspective? Should it adopt a target for money supply growth or inflation?

* How reliable is monetary policy controlling monetary variables such as money supply and interest rate .........and so on?

* Should the government control the activities of central bank or the central bank be given independence to conduct monetary policy as it sees fit?

\section{Second: Monetary policy in Syria}

1- What is interest rate?

The rate of interest has two roles:

* To the borrower: The rate of interest is the payment which has to be made in order to obtain liquid assets namely cash.

* To the lender: it is the reword received for parting with liquid assets.

It is important to distinguish between two kinds of interests:

1. Nominal interest rate or money rate: is the annual amount paid on funds which are borrowed.

2. The real interest rate : takes account of inflation

\section{Real interest rate $=$ Nominal interest rate - inflation rate.}

\section{How does the interest rate do?}

There are three cases?

- Reduce money supply and accept what ever equilibrium interest rate. The results, if money supply reduces (as example) a new higher rate of interest will result.

- Raise interest rate and then manipulate the money supply to reduce it and vice versa.

- Keep interest rate low in order to keep down the cost of investment also reduce money supply.

The interest rate policy :

Monetary policy in Syria remains inflexible and poorly managed. Using the interest rate in 2003 was the first alteration in more than 20 years and not has been successfully.

This alteration leads to:

* High increase in land prices.

* High Decrease in exchange rate.

* Weak the confidence in banks, economic, and currency.

The current interest rate policy in Syria focuses on restructure the deposits

In banks to the benefit of the long term deposits rather than short term deposits. 
For this reason Credit and Monetary Council (CMC) raised the interest rate on the long term deposits and decrease it on current accounts.

Why (cmc) follows this policy?

1. Encourage saving money in banks by giving savers high interest rate.

2. Decrease the amount of money under the banks use.

3. Raise banks ability to lend money.

4. Encourage investments by using banks surplus.

2- The meaning of the exchange rate:

It is the price of the local currency valued by other countries currencies.

Kinds of exchange rate:

1. Direct exchange rate.

2. In direct exchange rate.

3. Derived exchange rate.

Systems of exchange rate:

1. Fixed exchange rate.

2. Controlling exchange rate.

3. Floating exchange rate.

\section{Exchange Rate Arrangement in syria:}

The exchange system in Syria is characterized by multiple exchange rates and a foreign exchange market segmented into public and private sector pools. The private sector has almost no access to the official pool. Sourced by public sector foreign exchange revenues channeled through the Commercial Bank of Syria, and conducts its transactions on an unofficial parallel market located in Syria and offshore, sourced by foreign exchange from tourism, workers' remittances, proceeds from unrecorded exports, and private capital inflows.

Under the multiple rate structure, there are three official rates pegged to the dollar and one unofficial (market determined) rate.

A- Official rates (in 2011):

1. Legally designated official rate $(11.25 \mathrm{ls} / \$)$ :

Type of transaction:

Law 25 of 6/16/2004 abolishes the use of this rate for all transaction except service of debt under some payment agreement.

2. Public sector transaction rate $(50 \mathrm{ls} / \$)$ :

Type of transaction:

- Public sector exports of crude oil and petroleum.

- Public sector imports.

- Exports of Public sector enterprises.

- Earning of staff of UN and diplomatic missions in Syria

- External loans and grants.

3. Private sector transaction rate $(50-51.65 \mathrm{ls} / \$)$ :

Type of transaction:

- Private exports.

- Private sector receipts.

- Private sector purchases of noncommercial transaction (Medical, student ......Etc) .

- A few public invisible transactions.

B- Unofficial rate (in 2011):

Parallel market rate (52- $60 \mathrm{ls} / \$)$ :

Type of transaction:

- Private unrecorded exports and imports.

- Private sector receipts and payment.

- Private capital inflows. 
This figure illustrates the new changes in the exchange rate in Syria:

Parallel Market and Private Sector Official Exchange Rates 1/

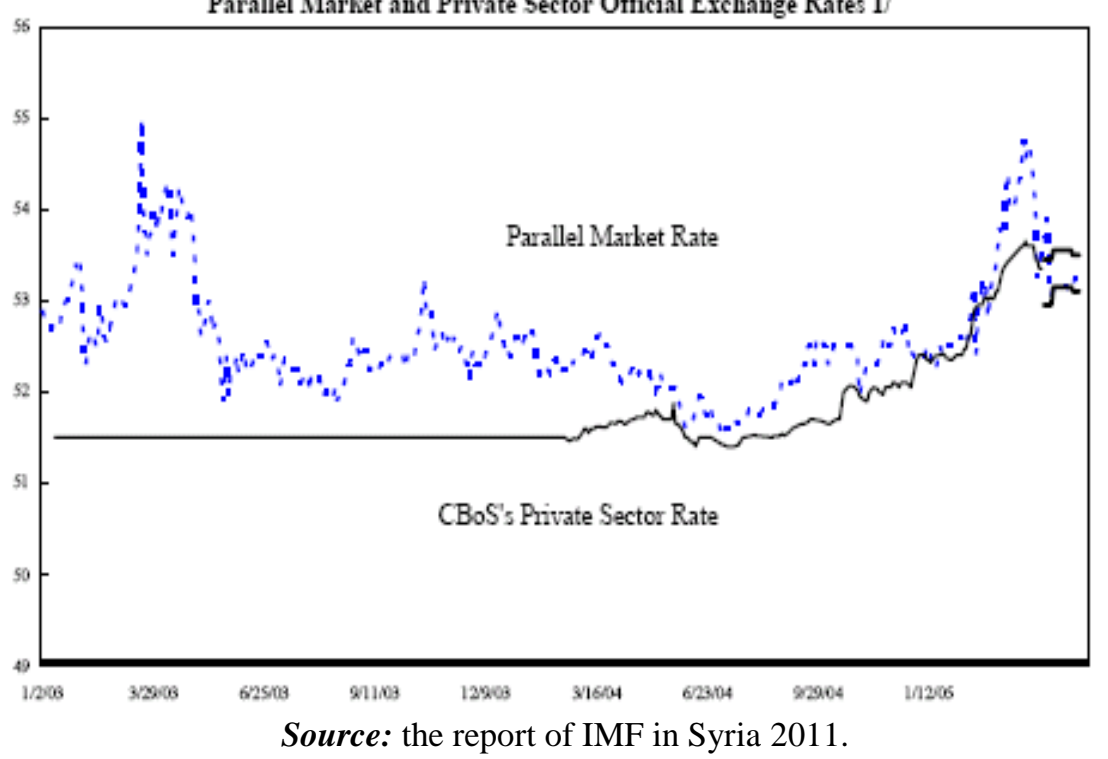

Syrian monetary authority determined an aim to gather this four exchange rates in only one exchange rate the market exchange rate .

Another aim is to shift gradually from the controlling exchange rate system to the floating exchange rate system.

Third: The role of the monetary policy in development process

The role of the monetary policy in development process in Syria can be noticed in this figure:

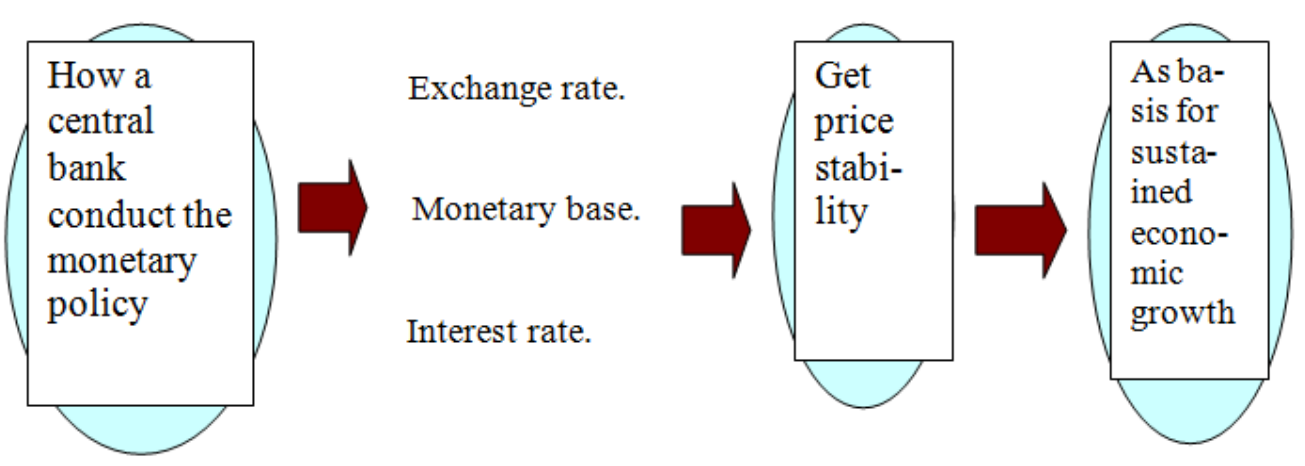

Objective of the monetary policy is different from one country to other countries .in Syria the principal goal of the monetary policy is to achieve economic growth.

The monetary policy is an important element in the economic policy in development process and its important derived from its tools.

How can the monetary policy achieve economic growth?

1- Treating inflation:

Inflation in the developing countries is always either:

* Demand inflation.

* Structure inflation.

These two types created within the economic development process in this country.

For this reason the monetary policy is very important in absorbing the surplus demand resulting from the government expenditure for development which leads to price stability.

The question here is: is the inflation necessary or helpful for development?

inflation alters income distribution in favor of profit - receivers can lead to larger amounts of investment than would be occur under stable economic conditions because of that profit receivers save a higher portion of their income than others do, although the high social cost.

2- Encouraging saving and investment:

There is a very strong relation between the amount of money available for investment and the economic growth. 
For this reason the government uses the tools of the monetary policy to attract the money from the house hold sector to the banks to make it usable to investors.

But in Syria there was no determined policy in this field the evidence is fixing the interest rate at the period [1981 - 2002] for both borrowers and lenders .that means defeat the interest rate as an important tool of the monetary policy in encouraging saving and investment.

The role of monetary policy is expected in general to play important role in development process in Syria

What can expect from monetary policy to enhance economic development in Syria?

The monetary policy can certainly help in three different ways:

- Maintaining financial stability.

- Channeling credit to the proper sectors of the economy.

- Establishing special credit institutions.

1- Maintaining financial stability:

- Maintaining internal and external stability would perhaps be the most important job of the monetary policy.

The rate of expansion in the money supply must be consistent with internal stability.

The reasonability of the monetary authority is to regulate the demand for money in such way to maintain internal financial stability.

- The external stability achieved by equiponderate of payment balance.

2- Channeling credit to the proper sectors of the economy.

The central bank can contribute in the economic development of Syria through channeling credit to their needs. This involves also the avoidance of letting the credit flow to undesired channels such as speculative activities.

A very special problem that will face the central bank is that of agricultural credits.

The agricultural sector is the major sector in Syrian economy, but its problem is bad debts and low productivity. Allocating resources between sectors can be made by the tools of the monetary policy especially using favored interest rates and rediscount rate.

3- Establishing special credit institutions:

The central bank can help establishing special credit and savings institutions which are needed.

Central bank in this connection will serve to stimulate savings that are (shy and afraid) or none accustomed to deal with institutions.

The growth in savings depends upon the increase in productive power and rise in national income.

Development banks are also needed and the central bank can help establishing them.

It is very logical that the government which aim is promoting economic development should encourage the growth of necessary institutions that will pursue the policies of development and increase the volume of savings and investment.

\section{Forth: Conclusions and recommendations}

We can say that the monetary policy plays big role in different economics.

In developing countries specially in Syria the monetary policy start to

Take its turn in affecting economy after rebirth in 2003 and give it the independence in practicing the monetary policy.

That is meaning the allowing to the economic laws to work far from the government wants.

From the Syrian experience in this concern at the last three years we can say that we need some time to a good use of the tools of monetary policy and we must re design our policies to fit our requirement.

\section{References}

[1]. Sloman, John: economics, England, 2000.

[2]. Economic intelligence unit: country report, 2005

[3]. International Monetary Fund: IMF Country Report, 2005.

[4]. www.eiu.com .

[5]. www.mas.gov.sg .

[6]. Taylor, JohnB: recent developments in the use of monetary policy rules, Stanford University, 2000.

[7]. Ison, Steven: economics, England.

[8]. Mardini, Adnan: monetary policy in Syria, Damascus.

[9]. Abdul-Zamil, Khalid: The Role of Monetary Policy in the Design of Economic Policy, PhD Thesis, University of Damascus, 2005.

[10]. Jomah, Muhammad Saleh: Monetary Policy in Syria, Dar al-Redha, Damascus, 2005.

[11]. Akain felgr, l'Aglérie pour suit la diversification économique et la transition bulletion, ( FMI ; 05 Août 1996)\.

[12]. CNES, Rapprt sur la conjoncture économique et social du $2^{\text {ème }}$ semestre $2001200^{\text {ème }}$ session plénière, 